\title{
Effects of Phosphoenolpyruvate, Other Glycolytic Intermediates and Methylxanthines on Calcium Uptake by a Mitochondrial Fraction from Rat Pancreatic Islets
}

\author{
M. C. Sugden and S. J. H. Ashcroft \\ Department of Clinical Biochemistry, Radcliffe Infirmary, Oxford, England
}

Summary. ${ }^{45} \mathrm{Ca}^{2+}$-accumulation by a mitochondrial fraction from isolated rat pancreatic islets was strongly stimulated by ATP. The ATP-dependent uptake was inhibited by phosphoenolpyruvate in a dose-dependent manner over a wide variety of conditions. Inhibition by phosphoenolpyruvate was noncompetitive with respect to calcium, competitive with respect to magnesium, and antagonised by high $\mathrm{Mg}$ ATP $^{2-}$ concentrations; fructose 1,6-diphosphate also decreased ${ }^{45} \mathrm{Ca}^{2+}$-uptake. Other glucose metabolites were either less effective or ineffective in diminishing mitochondrial ${ }^{45} \mathrm{Ca}^{2+}$-accumulation. The ATPdependent uptake was also inhibited by xanthine derivatives (caffeine and 3-isobutyl-1-methylxanthine) which potentiate the effects of glucose on insulin secretion. Cyclic AMP had no effect. It is thought that the rate of insulin secretion is a function of the cytosolic calcium concentration in the B-cell. These data show that phosphoenolpyruvate, fructose 1,6diphosphate and methylxanthines might influence exocytosis by direct effects on mitochondrial calcium accumulation, and thus the intracellular distribution of calcium.

Key words: Islets of Langerhans, insulin, glucose, phosphoenolpyruvate, substrate-site, methylxanthines, cyclic AMP, calcium, mitochondria, fructose 1,6-diphosphate

Changes in extracellular glucose concentration may lead, through changes in rates of glucose metabolism, to an alteration in the concentration of one or more key metabolic intermediates that may act as intracellular modulators of the rate of insulin release (the substrate-site hypothesis, [1]). We have recently sug- gested that phosphoenolpyruvate (PEP) may be one such modifier on the basis of parallel changes in islet PEP content and insulin release rate under various conditions [2]. In this paper we present data which indicate a way in which PEP could influence insulin secretion. The event most closely linked to exocytosis is believed to be a rise in B-cell cytosolic $\mathrm{Ca}^{2+}$ concentration: we show here that the uptake of ${ }^{45} \mathrm{Ca}^{2+}$ by a subcellular (mitochondrial) fraction from rat islets is markedly influenced by PEP.

\section{Materials and Methods ${ }^{1}$}

\section{Materials}

Collagenase (type 1) and bovine albumin (fraction V) were from Sigma (London) Chemical Co., Kingston-on-Thames, Surrey, U. K. The BSA was defatted as described by Chen [3] and extensively dialysed $(16 \mathrm{hr})$ against $\mathrm{KCl}(125 \mathrm{mmol} / \mathrm{l})$-tris- $\mathrm{HCl}$ $(20 \mathrm{mmol} / \mathrm{l}) \mathrm{pH}$ 7.4. IBMX was obtained from Aldrich Chemical Co., Milwaukee, Wisc., U.S.A. PEP (tricyclohexylammonium salt), fructose-1,6-diphosphate (trisodium salt), glycerate 2,3diphosphate (pentacyclohexylammonium salt), 6-phosphogluconate (trisodium salt), 3-phosphoglycerate (tricyclohexylammonium salt), 2-phosphoglycerate (trisodium salt or free acid), glucose-6-phosphate (disodium salt), glucose-1-phosphate (dipotassium salt) and pyruvate (monosodium salt) were from the Boehringer Corp. (London) Ltd., London, W. 5., U. K. ${ }^{45} \mathrm{CaCl}_{2}$ $(1.95 \mathrm{mCi} / \mathrm{ml})$ was from the Radiochemical Centre, Amersham, Bucks, U. K. Other reagents and enzymes were from Boehringer or Sigma. Chemicals were from British Drug Houses and were of the purest grade available.

\footnotetext{
I Abbreviations: The following abreviations have been used in the text and tables: PEP, phosphoenolpyruvate; BSA, bovine albumin; EDTA, ethylenediaminetetraacetic acid; IBMX, 3isobutyl-1-methylxanthine; cyclic AMP, cyclic 3',5'-adenosine monophosphate; ATP, adenosine triphosphate; ATPase, adenosine triphosphatase; Ca-ATPase, calcium-activated adenosine triphosphatase; FCCP, carbonylcyanide $p$-trifluoromethoxy-phenylhydrazone; DNP, 2,4-dinitrophenol
} 


\section{Methods}

Preparation of Islets: Islets were prepared by the method of Coll Garcia and Gill [4] from the pancreases of 200-300 g male albino Wistar rats fed ad libitum on standard laboratory diet.

Preparation of Mitochondria: The mitochondrial preparation medium was modified from that of Hodarnau et al. [5]. Islets (300) were collected in $100 \mu \mathrm{l}$ of homogenisation buffer, which contained mannitol $(210 \mathrm{mmol} / \mathrm{l})$, sucrose $(70 \mathrm{mmol} / \mathrm{l})$, tris- $\mathrm{HCl}$ $(10 \mathrm{mmol} / 1) \mathrm{pH} 7.4$, EDTA $(5 \mathrm{mmol} / 1)$ and BSA $(5 \mathrm{~g} / \mathrm{l})$, and homogenised in a glass homogeniser with a teflon pestle. The clearance between the pestle and the homogeniser was $0.4 \mathrm{~mm}$. Homogenisation was effected by means of 25 passes of the pestle at a speed of $300 \mathrm{r}$. p. m. More vigorous homogenisation increased the yield of mitochondria (based on measurements of the activity of citrate synthase, an exclusively mitochondrial enzyme [6]) but the calcium-accumulating activity was reduced and the percentage of the calcium accumulation sensitive to FCCP was decreased, showing the mitochondria were less well coupled.

Nuclei and cell debris were sedimented by centrifugation of the homogenate at $600 \times \mathrm{g}$ for $5 \mathrm{~min}$ at $4^{\circ} \mathrm{C}$. The supernatant was removed using a disposable micropipette and retained. It contained $60 \%$ of the total homogenate citrate synthase. The pellet was re-extracted in the buffered sucrose, re-homogenised as before, and again centrifuged at $600 \times \mathrm{g}$ for $5 \mathrm{~min}$ at $4^{\circ} \mathrm{C}$. The pooled supernatants were added to a $10 \mathrm{ml}$ centrifuge tube containing $5 \mathrm{ml}$ of mannitol-sucrose-tris- $\mathrm{HCl}$ medium (mannitol $210 \mathrm{mmol} / 1$; sucrose $70 \mathrm{mmol} / 1$; and tris- $\mathrm{HCl} 10 \mathrm{mmol} / 1, \mathrm{pH} 7.4$ at room temperature) and centrifuged at $30,000 \times \mathrm{g}$ or $50,000 \times \mathrm{g}$ for $10 \mathrm{~min}$ to give a mitochondria-rich pellet. As the pellet obtained after the $50,000 \mathrm{~g}$ centrifugation contained the same percentage of calcium accumulating activity which was FCCP sensitive as that obtained from the $30,000 \mathrm{~g}$ centrifugation, and was easier to manipulate, the higher speed was generally used. The pellet was resuspended and washed by repeating the ultracentrifugation procedure. The yield of mitochondria was $16-20 \%$ of the total (based on citrate synthase activity measurements). The pellet was resuspended in $200-300 \mu l$ of mannitol-sucrose-tris- $\mathrm{HCl}$ medium by rubbing gently with a glass rod.

${ }^{45} \mathrm{Ca}$ Accumulation by Isolated Mitochondria: The calcium accumulation of islet mitochondria was measured by incubating them in ${ }^{45}$ calcium and then rapidly separating the particle-bound from free ${ }^{45}$ calcium on Millipore membranes, a method which has been successfully used in studies of calcium accumulation by mitochondria [7]. The data cannot, however, be used to draw conclusions about net calcium fluxes across the mitochondrial membranes.

Mitochondria ( $15 \mu \mathrm{l}$ of the suspension) were incubated at $30^{\circ} \mathrm{C}$ in a total of $100 \mu \mathrm{l}$ of tris- $\mathrm{KCl}$ medium $(\mathrm{KCl}, 125 \mathrm{mmol} / \mathrm{l}$; tris$\mathrm{HCl}, 20 \mathrm{mmol} / 1 \mathrm{pH} 7.4$ containing $10 \mathrm{mmol} / \mathrm{l} \mathrm{K}$-succinate and $200 \mu \mathrm{g} / \mathrm{ml} \mathrm{BSA}$ (unless otherwise stated) and the additions given in the text or tables. BSA was included in the incubation medium as it improves the respiratory coupling and calcium retention of heart mitochondria [8]. The concentrations of calcium and test substances given refer to the amounts of substances added. No attempt has been made to distinguish between free $\mathrm{Ca}^{2+}$ and total calcium. Incorporation of ${ }^{45} \mathrm{Ca}$ into mitochondria was initiated by the addition of ${ }^{45} \mathrm{CaCl}_{2}(20-80 \mu \mathrm{Ci} / \mu \mathrm{mol})$ after preincubation for $5 \mathrm{~min}$. The reaction was terminated by the addition of $1 \mathrm{ml}$ of icecold suspension medium and filtration through pre-wetted Millipore filters (pore diameter $0.45 \mu$ ). The filters were immediately washed with $7 \mathrm{ml}$ of ice-cold suspension medium, dried and placed in $10 \mathrm{ml}$ of toluene scintillation fluid $(4 \mathrm{~g}$ of 2 -(4-tert-butylphenyl)-5-(4-biphenylyl)-1,3,4-oxadiazole per litre toluene). Radioactivity was determined in an Isocap Scintillation counter
(Searle Instruments). The ${ }^{45} \mathrm{Ca}$ uptake into the particles never exceeded $5 \%$ of the total ${ }^{45} \mathrm{Ca}^{2+}$ in the incubation medium. Blank values, obtained by incubating tris- $\mathrm{KCl}$ medium, ${ }^{45} \mathrm{CaCl}_{2}$, and the various additions given in the text or tables in the absence of mitochondria, never exceeded $10 \%$ of the counts obtained in the presence of mitochondria. PEP did not influence the binding of ${ }^{45} \mathrm{Ca}^{2+}$ to the Millipore filters.

Analytical Methods: Citrate synthase was assayed at $30^{\circ} \mathrm{C}$ by a modification of the method of Srere et al. [9] as described by Coore et al. [10]. The mitochondrial suspensions were disrupted by freezing and thawing three times prior to estimation of enzyme activities. A milliunit of enzyme activity $(\mathrm{mU})$ was defined as the amount of enzyme converting $1 \mathrm{nmol}$ of substrate to product per min.

Because of the small amounts of experimental material available, conventional tests of the purity and function of the islet mitochondrial fractions, e.g. morphological characterisation and measurements of oxygen uptake and marker enzymes, could not be routinely carried out. The morphological identity of a typical fraction was examined by electron microscopy. It contained principally mitochondria and membrane fragments. Some secretory granules were also present. As we wished to investigate only the mitochondrial accumulation of calcium, filters were used of a pore size that permits the passage of secretory granules but not that of mitochondria $[11,12]$. In addition we included measurements of the calcium accumulation by the preparation in the presence of the uncoupler of oxidative phosphorylation, FCCP, in each experiment. The FCCP-insensitive accumulation gave an estimate of the nonspecific binding of calcium by the preparation and/or accumulation of calcium by non-mitochondrial components of the preparation. The FCCP-insensitive accumulation was always less than $12 \%$ of the total calcium accumulation. The difference between the accumulation observed in the presence and absence of FCCP was considered to be mitochondrial calcium accumulation, and was expressed relative to the amount of citrate synthase in the preparation.

The statistical significance of differences was assessed by Student's t-test.

\section{Results}

Calcium uptake was dramatically increased by addition of ATP to the incubation medium, the maximum effect being obtained at an ATP concentration of $4 \mathrm{mmol} / \mathrm{l}$ (Fig. 1a). $\mathrm{Mg}^{2+}$ ions were required and maximal accumulation occurred at a magnesium concentration of $5 \mathrm{mmol} / \mathrm{l}$ (Fig. $1 \mathrm{~b}$ ). Omission of a permeant anion (phosphate) reduced the binding to levels little above those observed in the presence of FCCP. The presence of phosphate concentrations up to $1 \mathrm{mmol} / 1$ greatly enhanced the ${ }^{45} \mathrm{Ca}^{2+}$ accumulation. Greater concentrations reduced the net ${ }^{45} \mathrm{Ca}^{2+}$ uptake (Fig. $1 \mathrm{c}$ ). The probable explanation is that excessive uptake of both $\mathrm{Ca}^{2+}$ and phosphate under these conditions so damages the mitochondria that $\mathrm{Ca}^{2+}$ uptake ceases prematurely [12]. We sought to establish the nature of the calcium-accumulating system by use of known inhibitors of mitochondrial calcium accumulation. Results are given in Table 1 . The uptake of ${ }^{45} \mathrm{Ca}^{2+}$ was inhibited $70 \%$ by DNP 


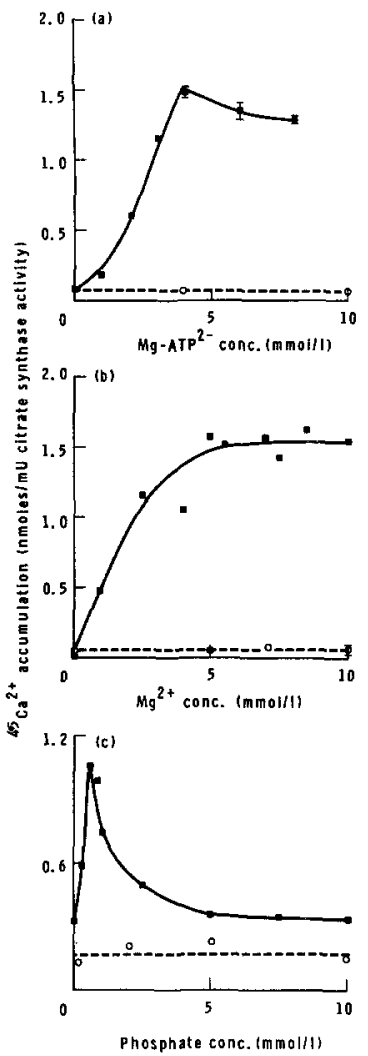

Fig. 1. Islet mitochondrial ${ }^{45} \mathrm{Ca}^{2+}$-uptake; effects of $\mathrm{Mg}$ - $\mathrm{ATP} \mathrm{P}^{2-}$, $\mathrm{Mg}^{2+}$ and phosphate. Mitochondria were incubated for $10 \mathrm{~min}$ at $30^{\circ} \mathrm{C}$ in tris- $\mathrm{KCl}$ medium containing ${ }^{45} \mathrm{CaCl}_{2}(0.22 \mathrm{mmol} / \mathrm{l})$ and a phosphate $(1 \mathrm{mmol} / \mathrm{l})$, and varying $\mathrm{Mg}-\mathrm{ATP}^{2-}$ concentrations. b ATP $(5 \mathrm{mmol} / \mathrm{l})$, phosphate $(1 \mathrm{mmol} / \mathrm{l})$, and varying $\mathrm{MgCl}_{2}$ concentrations. $\mathrm{c} \mathrm{Mg}-\mathrm{ATP}^{2-}(5 \mathrm{mmol} / \mathrm{l})$, and varying phosphate concentrations. The ${ }^{45} \mathrm{Ca}$ accumulated in the absence ( $\square$ ) and presence (o) of FCCP $(0.01 \mathrm{mmol} / \mathrm{l})$ is shown. Further details are given in the Materials and Methods section

Table 1. Islet mitochondrial ${ }^{45} \mathrm{Ca}^{2+}$-uptake; effects of uncouplers, oligomycin and ruthenium red

\begin{tabular}{ll}
\hline $\begin{array}{l}\text { Additions to mitochondrial } \\
\text { incubation medium }\end{array}$ & $\begin{array}{l}{ }^{45} \mathrm{Ca}^{2+} \text { accumulation } \\
\text { (pmol/mU citrate synthase } \\
\text { activity) }\end{array}$ \\
\hline None & 582 \\
Oligomycin $(20 \mu \mathrm{g} / \mathrm{ml})$ & 101 \\
DNP $(0.1 \mathrm{mmol} / \mathrm{l})$ & 163 \\
Ruthenium red $(5 \mu \mathrm{g} / \mathrm{ml})$ & 34 \\
FCCP $(0.01 \mathrm{mmol} / \mathrm{l})$ & 35
\end{tabular}

Islet mitochondria were incubated for $10 \mathrm{~min}$ at $30^{\circ} \mathrm{C}$ in tris- $\mathrm{KCl}$ medium containing $\mathrm{Mg}-\mathrm{ATP}^{2-}(5 \mathrm{mmol} / \mathrm{l})$, phosphate $(1 \mathrm{mmol} / \mathrm{l})$, ${ }^{45} \mathrm{CaCl}_{2}(0.22 \mathrm{mmol} / \mathrm{l})$ and the additions shown. The results are given as the mean of duplicate determinations with a single preparation of mitochondria. The duplicates differed from each other by less than $5 \%$ of their means

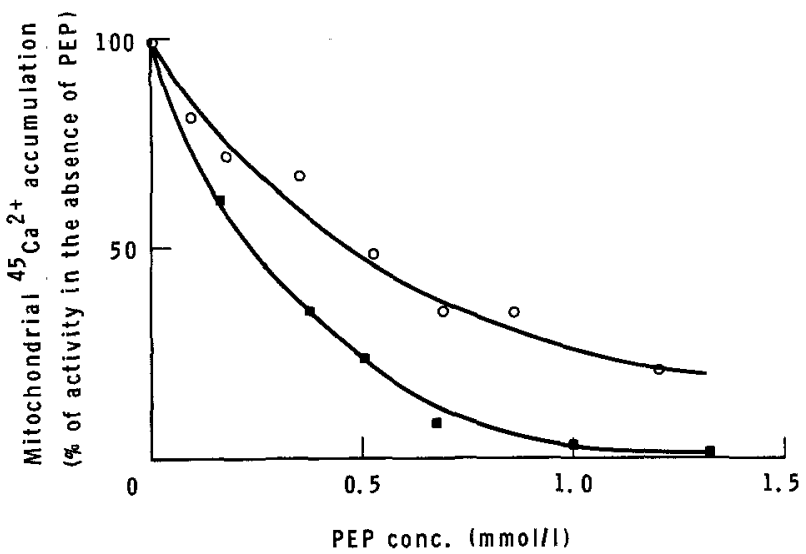

Fig. 2. Islet mitochondrial ${ }^{45} \mathrm{Ca}^{2+}$-uptake; effect of varying concentrations of PEP. Mitochondria were incubated for $10 \mathrm{~min}$ at $30^{\circ} \mathrm{C}$ in tris- $\mathrm{KCl}$ medium containing ${ }^{45} \mathrm{CaCl}_{2}, 0.02 \mathrm{mmol} / \mathrm{l}$; phosphate, $1 \mathrm{mmol} / 1$; ATP, $5 \mathrm{mmol} / \mathrm{l} ; \mathrm{MgCl}_{2} 5(0)$ or $1(\square) \mathrm{mmol} / \mathrm{l}$; and varying concentrations of PEP $(0-1.3 \mathrm{mmol} / 1)$. The ${ }^{45} \mathrm{Ca}^{2+}$ accumulation observed under each condition in the presence of FCCP $(0.01 \mathrm{mmol} / \mathrm{l})$ was subtracted from the ${ }^{45} \mathrm{Ca}^{2+}$ accumulation observed in the absence of FCCP. The results are expressed as percentages of the activity observed in the absence of PEP. The results were obtained using a single preparation of mitochondria

$(0.1 \mathrm{mmol} / \mathrm{l})$ and $80 \%$ by the respiratory inhibitor oligomycin $(20 \mu \mathrm{g} / \mathrm{ml})$. The potent uncoupler of oxidative phosphorylation, FCCP $(0.01 \mathrm{mmol} / \mathrm{l})$, reduced the calcium accumulation to $5 \%$ of the value observed in the absence of uncoupler. Accumulation was also inhibited to $5 \%$ of the control value by ruthenium red $(5 \mu \mathrm{g} / \mathrm{ml})$ which is reported to be a specific inhibitor of mitochondrial calcium uptake $[13,14]$ and does not inhibit calcium uptake by microsomes [15]. The extent of the inhibition of the calcium accumulation with every compound was similar to that observed for ATP-dependent calcium accumulation by fat-cell mitochondria [16]. Thus the characteristics of the calcium accumulation appeared to be consistent with those of ATP-dependent calcium accumulation into mitochondria. Experiments with islet mitochondria routinely included measurements of the calcium accumulation in the presence of FCCP.

It has recently been shown that addition of PEP causes release of calcium from liver and heart mitochondria [17-19]. Figure 2 shows the inhibition by PEP of ATP-stimulated calcium accumulation by the islet mitochondrial fraction. PEP $(0.1 \mathrm{mmol} / \mathrm{l})$ produced a decrease in calcium accumulation, and the degree of inhibition increased as the concentration of PEP was raised. In other experiments it was observed that the inhibitory effects of PEP were enhanced when the mitochondria were preincubated with PEP for more than one minute prior to calcium additon. Cyclohexylamine $(5 \mathrm{mmol} / 1$ in incubation 


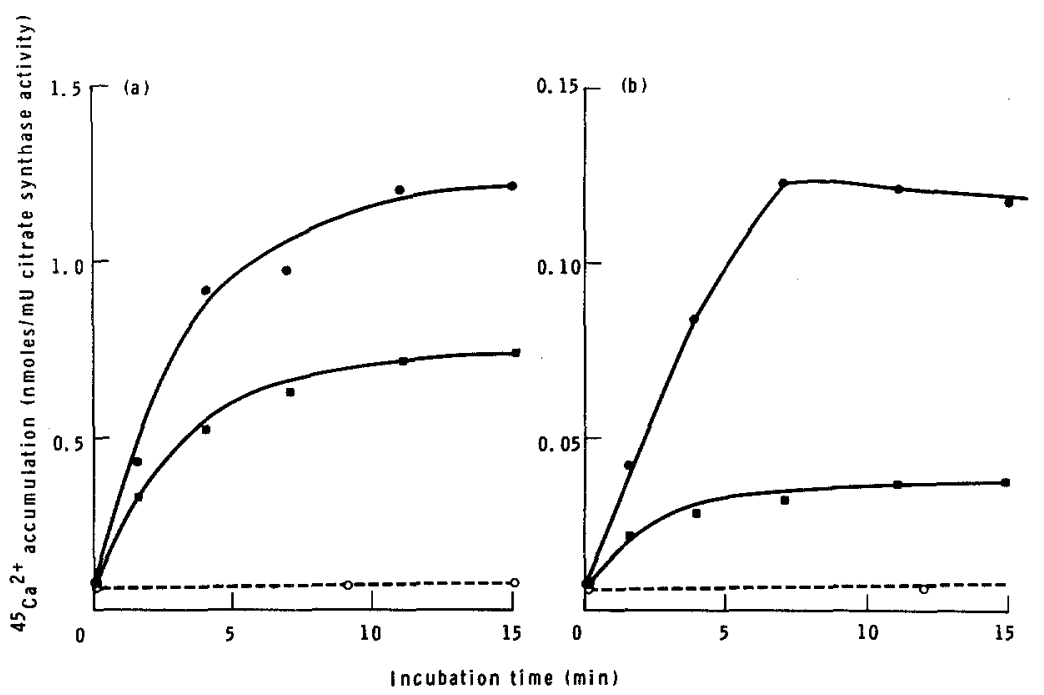

Fig. 3. Islet mitochondrial ${ }^{45} \mathrm{Ca}^{2+}-$ uptake; timecourse in the absence and presence of PEP. Mitochondria were incubated at $30^{\circ} \mathrm{C}$ for different periods of time in tris- $\mathrm{KCl}$ medium containing phosphate $(1 \mathrm{mmol} / \mathrm{l})$ and $\mathbf{a} \mathrm{MgCl}_{2}$ $(5 \mathrm{mmol} / 1)$ and ${ }^{45} \mathrm{CaCl}_{2}(0.22 \mathrm{mmol} / \mathrm{l})$ or b $\mathrm{MgCl}_{2}(1 \mathrm{mmol} / \mathrm{l})$ and ${ }^{45} \mathrm{CaCl}_{2}(0.02 \mathrm{mmol} / \mathrm{l})$ in the absence $(\bullet)$ or presence $(\square)$ of PEP $(1 \mathrm{mmol} / \mathrm{l})$. The ${ }^{45} \mathrm{Ca}^{2+}$ accumulation in the presence of FCCP $(0.01 \mathrm{mmol} / \mathrm{l})$ is also shown (o)
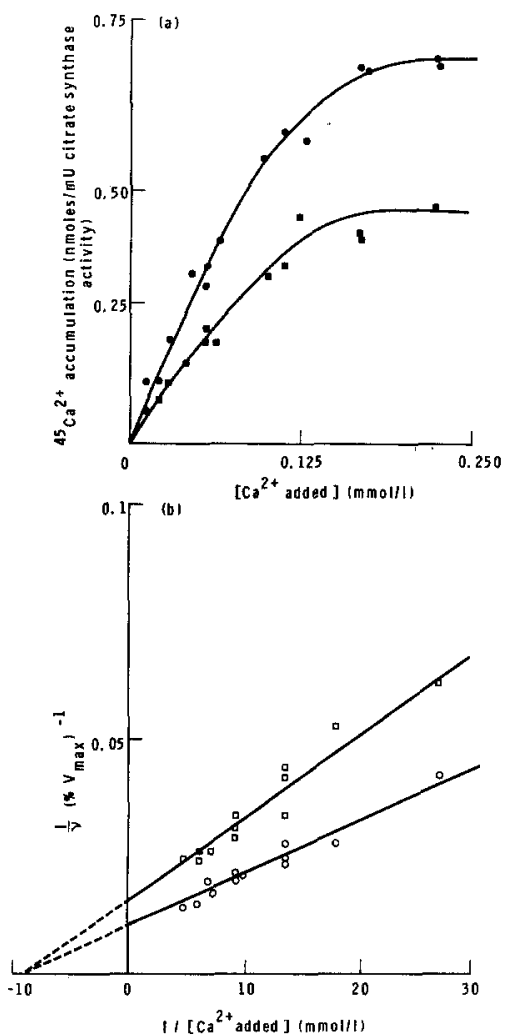

Fig. 4. Islet mitochondrial ${ }^{45} \mathrm{Ca}^{2+}$-uptake; dependence on calcium concentration in the absence and presence of PEP. a Mitochondria were incubated for $10 \mathrm{~min}$ at $30^{\circ} \mathrm{C}$ in tris- $\mathrm{KCl}$ medium containing $\mathrm{Mg}-\mathrm{ATP}^{2-}, 5 \mathrm{mmol} / \mathrm{l}$; phosphate, $1 \mathrm{mmol} / \mathrm{l}$; and varying ${ }^{45} \mathrm{CaCl}_{2}$ concentrations in the absence $(\bullet)$ and presence $(\boldsymbol{\omega})$ of PEP $(1 \mathrm{mmol} / 1)$. Further details are given in the Materials and Methods section. b A reciprocal plot of ${ }^{45} \mathrm{Ca}^{2+}$ accumulation at various concentrations of ${ }^{45} \mathrm{CaCl}_{2}$ in the absence (o) and presence $(\square)$ of PEP $(1 \mathrm{mmol} / \mathrm{l})$ is shown. Assays were run for $3.5 \mathrm{~min}$ at $30^{\circ} \mathrm{C}$ in tris- $\mathrm{KCl}$ medium containing the same additions as (a). In order to combine data obtained with three preparations of mitochondria with slightly different calcium accumulating activities, initial velocities were expressed as a percentage of the $V_{\text {max }}$ in each case buffer) was sometimes observed to inhibit calcium uptake by a small amount (5-10\%). However, this inhibition was never statistically significant and, in addition, the cyclohexylamine concentrations in these controls were approximately two fold greater than any added as PEP-tricyclohexylammonium salt.

Time courses for the calcium accumulation, under two sets of conditions, in the presence and absence of PEP, are shown in Figure 3. Maximum calcium accumulation occurred after $10 \mathrm{~min}$ both in the presence and absence of PEP but the plateau levels observed in the presence of PEP were lower than those observed in the absence of PEP. At the lower $\mathrm{Mg}^{2+}$ and $\mathrm{Ca}^{2+}$ concentrations the plateau level observed in the presence of PEP was $29 \%$ of that observed in the absence of PEP. At the higher $\mathrm{Mg}^{2+}$ and $\mathrm{Ca}^{2+}$ concentrations the plateau level reached in the presence of PEP was $62 \%$ of that observed in the absence of PEP.

The effect of varying the calcium and magnesium concentrations on the inhibition of ATP-linked calcium accumulation by PEP was studied. The inhibition by PEP was observed over a range of calcium concentrations (Fig. 4 a). Initial rate studies showed that the $\mathrm{K}_{\mathrm{m}}$ for added calcium was $0.13 \mathrm{mmol} / \mathrm{l}$, and that inhibition by PEP was non-competitive with respect to calcium (Fig. $4 \mathrm{~b}$ ). The $\mathrm{K}_{\mathrm{i}}$ for PEP was $2.03 \mathrm{mmol} / 1$. However the PEP inhibition was competitive with respect to $\mathrm{Mg}^{2+}$. The $\mathrm{K}_{\mathrm{m}}$ for $\mathrm{Mg}^{2+}$ was $2.32 \mathrm{mmol} / \mathrm{l}$, and the $\mathrm{K}_{\mathrm{i}}$ for PEP was $0.30 \mathrm{mmol} / 1$ (Fig. 5).

The degree of inhibition of net calcium uptake produced by the addition of PEP $(1 \mathrm{mmol} / \mathrm{l})$ was antagonised by increasing the $\mathrm{Mg}-\mathrm{ATP}^{2-}$ concentration (Fig. 6). However, even in the presence of $10 \mathrm{mmol} / \mathrm{l} \mathrm{Mg}-\mathrm{ATP}^{2-}$ there was still significant inhi- 


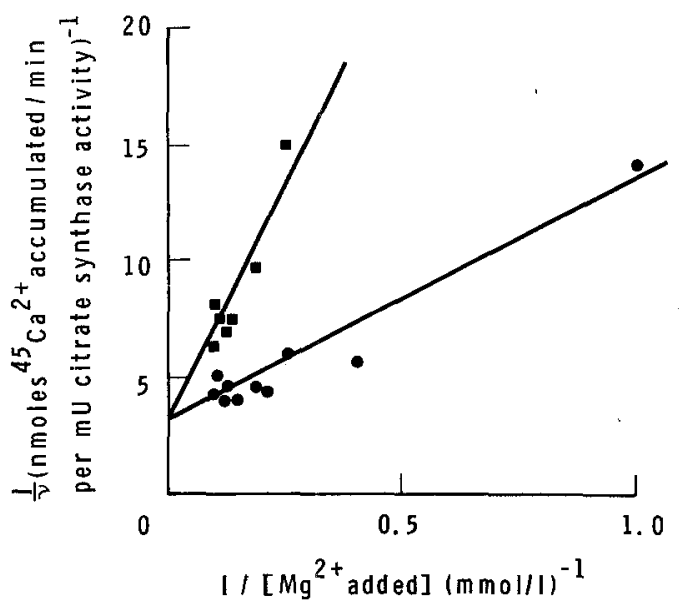

Fig. 5. Islet mitochondrial ${ }^{45} \mathrm{Ca}^{2+}$-uptake; dependence on magnesium concentration in the absence and presence of PEP. Reciprocal plots of ${ }^{45} \mathrm{Ca}^{2+}$ accumulation at various concentrations of $\mathrm{MgCl}_{2}$ in the absence $(\bullet)$ or presence $(\boldsymbol{\omega})$ of PEP $(1 \mathrm{mmol} / \mathrm{l})$ are shown. Mitochondria were incubated for $3.5 \mathrm{~min}$ at $30^{\circ} \mathrm{C}$ in tris$\mathrm{KCl}$ medium containing, in addition, ATP, $5 \mathrm{mmol} / 1$; phosphate, $1 \mathrm{mmol} / \mathrm{l}$; and ${ }^{45} \mathrm{CaCl}_{2}, 0.22 \mathrm{mmol} / 1$

bition of ATP-linked calcium accumulation [0.91 \pm $0.06(n=3)$ and $1.32 \pm 0.07(n=3)$ nmoles of ${ }^{45} \mathrm{Ca}^{2+}$ accumulated/10 min per $\mathrm{mU}$ citrate synthase activity in the presence and absence of PEP respectively $(\mathrm{p} \leqslant 0.01)]$

The PEP inhibition was observed over a range of phosphate concentrations and the degree of inhibition was independent of the phosphate concentration (Fig. 7). Thus PEP does not appear to act by interfering with phosphate transport. Chudapongse and Haugaard, working with liver mitochondria, have also found that increasing the phosphate concentration of the medium did not diminish the action of PEP [17].

Glucose metabolites other than PEP were examined for their effectiveness in diminishing calcium accumulation under two sets of conditions (Table 2). Only fructose 1,6-diphosphate (FDP) inhibited uptake at both low and high $(p \leqslant 0.001$ versus control) divalent metal ion concentrations. This inhibition was not caused by the presence of $\mathrm{Na}^{+}$(the counterion for FDP) since $\mathrm{NaCl}$, added to the same concentration in the absence of FDP, did not have any effect. The decreases in calcium accumulation produced by glycerate 2,3 -diphosphate $(p \leqslant 0.05$ versus control) and 6-phosphogluconate ( $p$ $\leqslant 0.02$ versus control) at the low divalent metal ion concentrations were overcome by increasing the calcium and magnesium concentrations, suggesting that they might be acting by chelating one or both of these ions. There was some inhibition by 3 -phosphoglycerate $(p \leqslant 0.01$ versus control) at the high calcium

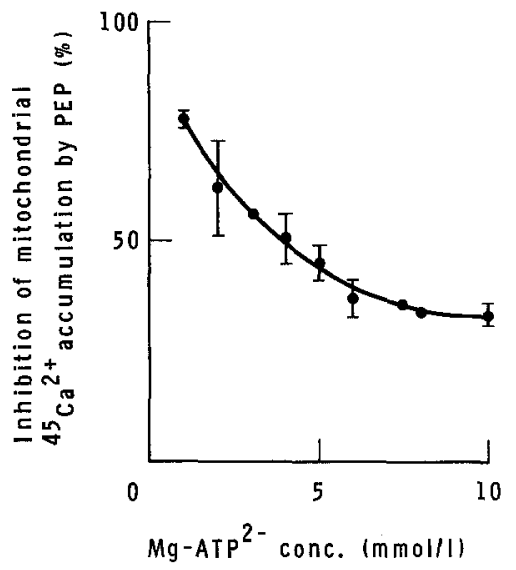

Fig. 6. Islet mitochondrial ${ }^{45} \mathrm{Ca}^{2+}$-uptake; effects of $\mathrm{Mg}-\mathrm{ATP} \mathrm{P}^{2-}$ concentration on the degree of inhibition produced by $P E P$. Islet mitochondria were incubated for $10 \mathrm{~min}$ at $30^{\circ} \mathrm{C}$ in tris- $\mathrm{KCl}$ medium containing phosphate, $1 \mathrm{mmol} / 1 ;{ }^{45} \mathrm{CaCl}_{2}, 0.22 \mathrm{mmol} / \mathrm{l}$; and varying concentrations of $\mathrm{Mg}-\mathrm{ATP}^{2-}$, in the presence or absence of PEP $(1 \mathrm{mmol} / \mathrm{l})$. The ${ }^{45} \mathrm{Ca}^{2+}$ accumulation observed under each condition in the presence of FCCP $(0.01 \mathrm{mmol} / \mathrm{l})$ was subtracted from the ${ }^{45} \mathrm{Ca}^{2+}$ accumulation observed in the absence of FCCP. The results are expressed as the percentage decrease produced by PEP of the calcium accumulation in the absence of PEP. Mean values \pm SEM are derived from 3 observations

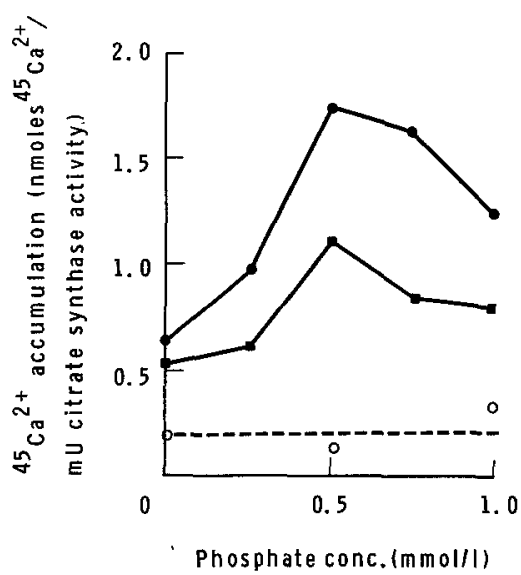

Fig. 7. Islet mitochondrial ${ }^{45} \mathrm{Ca}^{2+}$-uptake; effect of phosphate concentration on the inhibition by PEP. Incorporation of ${ }^{45} \mathrm{Ca}^{2+}$ into islet mitochondria was determined after $10 \mathrm{~min}$ incubation at $30^{\circ} \mathrm{C}$ in tris- $\mathrm{KCl}$ medium containing ${ }^{45} \mathrm{CaCl}_{2}, 0.22 \mathrm{mmol} / 1 ; \mathrm{Mg}$ $\mathrm{ATP}^{2-}, 5 \mathrm{mmol} / 1$; and varying phosphate concentrations in the absence $(\bullet)$ and presence of $(\square)$ of PEP $(1 \mathrm{mmol} / 1),{ }^{45} \mathrm{Ca}^{2+}$ accumulation in the presence of FCCP $(0.01 \mathrm{mmol} / \mathrm{l})$ is also shown (o). Further details are given in the Material and Methods section

concentrations. Chudapongse and Haugaard also observed decreased calcium accumulation by liver mitochondria in the presence of 3-phosphoglycerate, and suggested that it was possibly converted to PEP by glycolytic enzymes contaminating the mitochondrial preparation [17]. 2-Phosphoglycerate slightly increased the calcium accumulation $(\mathrm{p} \leqslant 0.05$ versus 
Table 2. Islet mitochondrial ${ }^{45} \mathrm{Ca}^{2+}$-uptake; effects of glucose metabolites

\begin{tabular}{lcc}
\hline Additions & $\begin{array}{l}\text { \% of control accumulation } \\
\text { observed under conditions: }\end{array}$ \\
\hline & I & II \\
None & 100 & 100 \\
PEP & $54.1 \pm 5.2(9)$ & $45.2 \pm 3.7(9)$ \\
Fructose-1,6-diphosphate & 67.9 & $56.1 \pm 2.7(4)$ \\
Glycerate 2,3-diphosphate & 75.7 & 105.5 \\
6-phosphogluconate & $71.0 \pm 5.5(4)$ & 99.1 \\
3-phosphoglycerate & 107.8 & $77.8 \pm 3.9(4)$ \\
2-phosphoglycerate & $113.4 \pm 2.63(4)$ & 101.3 \\
\hline
\end{tabular}

Islet mitochondria were incubated for $10 \mathrm{~min}$ at $30^{\circ} \mathrm{C}$ in tris- $\mathrm{KCl}$ medium containing ATP $(5 \mathrm{mmol} / \mathrm{l})$ and phosphate $(1 \mathrm{mmol} / \mathrm{l})$. Under condition $\mathrm{I}$, this medium was supplemented with $\mathrm{MgCl}_{2}$ $(1 \mathrm{mmol} / \mathrm{l})$ and BSA $(25 \mu \mathrm{g} / \mathrm{ml})$ and the $\mathrm{CaCl}_{2}$ concentration was $0.02 \mathrm{mmol} / 1$. Under condition $\Pi$, this medium was supplemented with $\mathrm{MgCl}_{2}(5 \mathrm{mmol} / \mathrm{l})$, BSA $(200 \mu \mathrm{g} / \mathrm{ml})$ and the ${ }^{45} \mathrm{CaCl}_{2}$ concentration was $0.22 \mathrm{mmol} / 1$. All glucose metabolites were added at a final concentration of $1.5 \mathrm{mmol} / \mathrm{l}$. The ${ }^{45} \mathrm{Ca}^{2+}$ accumulation observed under each condition in the presence of FCCP $(0.01 \mathrm{mmol} / \mathrm{l})$ was subtracted from the ${ }^{45} \mathrm{Ca}^{2+}$ accumulation observed in the absence of FCCP. Results are expressed as the percentage of the calcium accumulated in the control (no addition) incubations given as the mean \pm SEM for the number of observations stated in parentheses, or as the mean of duplicates. The duplicates differed from each other by less than $6 \%$ of their mean values. The control value under condition I was $24.2 \pm 2.8$ (9) pmol ${ }^{45} \mathrm{Ca}^{2+}$ accumulated/10 min/mU citrate synthase. The control value under condition II was $394.4 \pm 22.1$ (9) $\mathrm{pmol}^{45} \mathrm{Ca}^{2+}$ accumulated $/ 10 \mathrm{~min} / \mathrm{mU}$ citrate synthase

Table 3. Islet mitochondrial ${ }^{45} \mathrm{Ca}^{2+}$-uptake; effects of cyclic AMP, caffeine and IBMX

\begin{tabular}{ll}
\hline $\begin{array}{l}\text { Additions to mitochondrial } \\
\text { incubation medium }\end{array}$ & $\%$ of control accumulation \\
\hline None & 100 \\
cyclic AMP $(0.01 \mathrm{mmol} / \mathrm{l})$ & $95.5 \pm 7.4(4)$ \\
cyclic AMP $(0.01 \mathrm{mmol} / \mathrm{l})+$ & 48.4 \\
IBMX $(1 \mathrm{mmol} / \mathrm{l})$ & $48.6 \pm 1.5(4)$ \\
IBMX $(1 \mathrm{mmol} / \mathrm{l})$ & 74.3 \\
caffeine $(1.5 \mathrm{mmol} / \mathrm{l})$ & 53.8 \\
caffeine $(5 \mathrm{mmol} / \mathrm{l})$ & $32.6 \pm 2.4(6)$ \\
caffeine $(10 \mathrm{mmol} / \mathrm{l})$ & $10.8 \pm 1.3(4)$ \\
FCCP $(0.01 \mathrm{mmol} / \mathrm{l})$ & \\
\hline
\end{tabular}

Incorporation of ${ }^{45} \mathrm{Ca}^{2+}$ into islet mitochondria was determined after $10 \mathrm{~min}$ incubation at $30^{\circ} \mathrm{C}$ in tris- $\mathrm{KCl}$ medium containing ${ }^{45} \mathrm{CaCl}_{2} \quad(0.22 \mathrm{mmol} / \mathrm{l})$, phosphate $(1 \mathrm{mmol} / \mathrm{l}), \quad \mathrm{Mg}-\mathrm{ATP}^{2-}$ $(5 \mathrm{mmol} / \mathrm{l})$ and other additions as indicated. Results are expressed as the percentage of the calcium accumulated in the control (no addition) incubations given as mean \pm SEM for the number of observations stated in parentheses, or as the mean of duplicates. The duplicates differed from each other by less than $7 \%$ of their mean values. The control value was $471.5 \pm 6.2(4) \mathrm{pmol}^{45} \mathrm{Ca}^{2+}$ accumulated $/ 10 \mathrm{~min} / \mathrm{mU}$ citrate synthase control). Glucose-6-phosphate, glucose-1-phosphate and pyruvate did not significantly diminish calcium accumulation under either condition (results not shown).

In view of the involvement of cyclic AMP in insulin secretion, the effects of cyclic AMP, caffeine and IBMX on calcium accumulation by isolated islet mitochondria were examined (Table 3). Cyclic AMP $(0.01 \mathrm{mmol} / \mathrm{l})$ did not inhibit calcium accumulation. IBMX $(1 \mathrm{mmol} / \mathrm{l})$ produced a $50 \%$ inhibition of calcium accumulation $(\mathrm{p} \leqslant 0.001$ versus control). Cyclic AMP $(0.01 \mathrm{mmol} / \mathrm{l})$ did not potentiate the inhibitory effect of IBMX. Caffeine inhibited calcium incorporation in a dose-dependent manner, $70 \%$ inhibition being observed with $10 \mathrm{mmol} / \mathrm{l}$ caffeine ( $p \leqslant 0.001$ versus control).

\section{Discussion}

Correlations observed between rates of insulin release, glucose metabolism and calcium uptake by the B-cell $[20,21]$ suggest the following hypothesis for the mechanism of glucose-induced insulin release. Changes in extracellular glucose concentration, through changes in rates of glucose metabolism, alter the concentration of one or more intermediates or cofactors that affect handling of calcium by the Bcell. An increase in cytosolic calcium concentration thus produced triggers the discharge of insulin from the B-cell. Alterations in the rates of calcium flux across the plasma membrane and into or out of intracellular organelles might be involved in the regulation of cytosolic calcium concentration. In an earlier study [2], we demonstrated that the PEP content of rat islets varied in parallel with rates of insulin release under various conditions. Since PEP had been shown to influence calcium uptake by mitochondria from other tissues [17-19], we suggested that PEP might be one compound capable of linking glucose metabolism and calcium handling by the B-cell. The present study provides direct support for this hypothesis: a significant reduction of the accumulation of calcium by an islet subcellular fraction was produced by physiological concentrations of PEP under a wide variety of conditions.

It has been shown that a microsomal fraction from islets shows ATP-dependent ${ }^{45} \mathrm{Ca}^{2+}$ accumulation $[22,23]$. However Howell et. al. [24] suggested that mitochondria might represent the major sites of calcium accumulation in B-cells as they contain high concentrations of exchangeable calcium and provide a far larger area for calcium transport than any other organelle [25]. The following considerations suggest that our data are representative of islet mitochondrial 
$\mathrm{Ca}^{2+}$ uptake. Firstly, in view of the preparative procedure $(50,000 \mathrm{~g}$ for $10 \mathrm{~min}$ in sucrose medium) we do not expect gross microsomal contamination of the fraction. Secondly, the effects of the various inhibitors of $\mathrm{Ca}^{2+}$-uptake are completely in accord with their effects on mitochondrial $\mathrm{Ca}^{2+}$-uptake by adipose tissue mitochondria [16]; in particular, although FCCP may inhibit both microsomal and mitochondrial $\mathrm{Ca}^{2+}$-uptake, ruthenium red has been reported to inhibit mitochondrial but not microsomal $\mathrm{Ca}^{2+}$-uptake [15]. Thirdly, since secretory granules contaminate the mitochondrial fraction, we have used a Millipore filter of $0.45 \mu$ pore-size to separate particle-bound ${ }^{45} \mathrm{Ca}^{2+}$ : islet secretory granules are not retained by such filters $[11,22]$ and thus ${ }^{45} \mathrm{Ca}^{2+}$ taken up by secretory granules will not contribute to the measured ${ }^{45} \mathrm{Ca}^{2+}$-uptake. Thus the present results emphasize the potential importance of mitochondrial calcium uptake in regulation of B-cell cytosolic calcium concentration: the calciumaccumulating activity and the distribution of the mitochondria may influence the magnitude, duration and location of changes in cytosolic calcium concentration in response to an influx of calcium from outside the cell. The inhibitory actions of PEP and FDP on mitochondrial calcium uptake could serve the physiological role of maintaining an elevated cytosolic calcium concentration (and increased exocytosis) following a glucose-induced influx of calcium. Whether these glycolytic intermediates may additionally be involved in the regulation of calcium influx across the plasma membrane is not known.

This study also indicates the possible importance of mitochondrial calcium uptake in the action of methylxanthines on insulin release. Although methylxanthines affect many cellular processes by inhibiting phosphodiesterase and thus increasing cyclic AMP concentration, direct actions on calcium mobilisation by sarcoplasmic reticulum [26] and on calcium uptake by an islet microsomal fraction [23] have been described. From measurements of islet cyclic AMP content and rates of insulin release, Capito and Hedeskov [27] postulated an action of methylxanthines on insulin release independent of inhibition of phosphodiesterase. Our results provide direct support for this suggestion. Both caffeine and IBMX greatly reduced islet mitochondrial calcium accumulation: this inhibition could not be duplicated by cyclic AMP. The mechanism is unknown but the finding of an inhibition of islet Ca-Mg ATPase by caffeine [28] may be relevant.

Acknowledgements. We thank Professor P. J. Randle for his interest and encouragement. This work was supported by grants from the Medical Research Council and the British Diabetic Association.

\section{References}

1. Randle, P. J., Ashcroft, S. J. H., Gill, J. R.: In: F. Dickens, P. J. Randle, W. J. Whelan (Eds.): Carbohydrate Metabolism and Its Disorders, Vol. 1, pp. 427-447. London: Academic Press 1968

2. Sugden, M. C., Ashcroft, S. J. H.: Phosphoenolpyruvate in rat pancreatic islets: a possible intracellular trigger of insulin release? Diabetologia 13, 481-486 (1977)

3. Chen, R. F.: Removal of fatty acids from serum albumin by charcoal treatment. J. Biol. Chem. 242, 173-181 (1967)

4. Coll Garcia, E., Gill, J. R.: Insulin release by isolated pancreatic islets of the mouse incubated in vitro. Diabetologia $\mathbf{5}$, 61-66 (1969)

5. Hodarnau, A., Dancea, S., Barzu, O.: Isolation of highly purified mitochondria from rat pancreas. J. Cell Biol. 59, 222-227 (1973)

6. Martin, B. R., Denton, R. M.: The intracellular location of enzymes in white-adipose-tissue fat cells and permeability properties of fat cell mitochondria. Biochem. J. 117, 861-877 (1970)

7. Carafoli, E., Gamble, R. L., Lehninger, A. L.: Rebounds and oscillations in respiration - linked movements of $\mathrm{Ca}^{2+}$ and $\mathrm{H}^{+}$in rat liver mitochondria. J. Biol. Chem. 241, 2644-2652 (1966)

8. Harris, E. J.: The uptake and release of calcium by heart mitochondria. Biochem. J. 186, 447-456 (1977)

9. Srere, P. A., Barzil, H., Conen, L.: The citrate condensing enzyme of pigeon breast muscle and moth flight muscle. Acta Chem. Scand. 17, S129-S134 (1963)

10. Coore, H. G., Denton, R.M., Martin, B. R., Randle, P. J.: Regulation of adipose tissue pyruvate dehydrogenase by insulin and other hormones. Biochem. J. 125, 115-127 (1971)

11. Clements, R. S., Rhoten, W. B., Starnes, W. R.: Subcellular localisation of the alterations in phosphatidylinositol metabolism following glucose-induced insulin release from rat pancreatic islets. Diabetes 26, 1109-1116 (1977)

12. Rossi, C. S., Lehninger, A. L.: Stoichiometry of respiratory stimulation, accumulation of $\mathrm{Ca}^{2+}$ and phosphate, and oxidative phosphorylation in rat liver mitochondria. J. Biol. Chem. 239, 3971-3980 (1964)

13. Moore, C. L.: Specific inhibition of mitochondrial $\mathrm{Ca}^{2+}$ transport by ruthenium red. Biochem. Biophys. Res. Commun. 42, 298-305 (1971)

14. Vasington, F. D., Gazotti, P., Tiozzo, R., Carafoli, E.: The effect of ruthenium red on $\mathrm{Ca}^{2+}$ transport and respiration in rat liver mitochondria. Biochim. Biophys. Acta 256, 43-54 (1972)

15. Bygrave, F. L.: Properties of energy-dependent calcium transport by rat liver microsomal fraction as revealed by initial-rate measurements. Biochem. J. 170, 87-91 (1978)

16. Severson, D. L., Denton, R.M., Pask, H. T., Randle, P. J.: Calcium and magnesium ions as effectors of adipose-tissue pyruvate dehydrogenase phosphate phosphatase. Biochem. J. 140, 225-237 (1974)

17. Chudapongse, P., Haugaard, N.: The effect of phosphoenolpyruvate on calcium transport by mitochondria. Biochem. Biophys. Acta 307, 599-606 (1973)

18. Sul, H.S., Shrago, E., Shug, A. L.: Relationship of phosphoenolpyruvate transport, acylcoenzyme $A$ inhibition of adenine nucleotide translocase, and calcium ion efflux in guinea pig heart mitochondria. Arch. Biochem. Biophys. 172, 230-237 (1976)

19. Peng, C. F., Price, D. W., Bhuvaneswaran, C., Wadkins, C. L.: Factors that influence phosphoenolpyruvate-induced calcium efflux from rat liver mitochondria. Biochem. Biophys. Res. Commun. 56, 134-141 (1974) 
20. Sener, A., Levy, J., Malaisse, W. J.: The stimulus-secretion coupling of glucose-induced insulin release. Does glycolysis control calcium transport in the B-cell? Biochem. J. 156, 521-525 (1976)

21. Ashcroft, S. J. H.: The control of insulin release by sugars. In: Ciba Foundation Symposium 41 (new series), pp. 117-139. Elsevier Amsterdam: Excerpta Medica/North-Holland 1976

22. Howell, S. L., Montague, W., Tyhurst, M.: Calcium distribution in islets of Langerhans: a study of calcium concentrations and of calcium accumulation in B-cell organelles. J. Cell Sci. 19, 395-409 (1975)

23. Sehlin, J.: Calcium uptake by subcellular fractions of pancreatic islets. Biochem. J. 156, 63-69 (1970)

24. Howell, S. L., Tyhurst, M.: Barium accumulation in rat pancreatic B-cells, J. Cell Sci. 22, 445-465 (1976)

25. Dean, P. M.: Ultrastructural morphometry of the pancreatic B-cell. Diabetologia 9, 115-119 (1973)

26. Nayler, W. G.: Effect of caffeine on cardiac contractile activity and radiocalcium movement. Am. J. Physiol. 204, 969-974 (1963)

27. Capito, K., Hedeskov, C. J.: Effects of starvation on phosphodiesterase activity and the content of adenosine $3^{\prime}, 5^{\prime}$-cyclic monophosphate in isolated mouse pancreatic islets. Biochem. J. 142, 653-658 (1974)

28. Formby, B., Capito, K., Egeberg, J., Hedeskov, C. J.: Ca-activated ATPase activity in subcellular fractions of mouse pancreatic islets. Am. J. Physiol. 230, 441-448 (1976)

Received: January 13, 1978,

and in revised form: March 28, 1978

Dr. S. J. H. Ashcroft

Department of Clinical Biochemistry

Radcliffe Infirmary

Oxford OX2 6HE

England 